\title{
Plasticity and Aesthetic Identity; or, Why We Need a Spinozist Aesthetics
}

\author{
Tom Sparrow
}

\begin{abstract}
AвSTRACт This essay defends the view that, as embodied, our identities are necessarily dependent on the aesthetic environment. Toward this end, it examines the renewal of the concept of sensation (aisthesis) in phenomenology, but then concludes that the methodology and metaphysics of phenomenology must be abandoned in favor of an ontology that sees corporeal identity as generated by the materiality of aesthetic relations. It is suggested that such an ontology is available in the work of Spinoza, which helps break down the natu$\mathrm{ral} /$ artificial and human/nonhuman distinctions, and can thereby engender an environmental ethics grounded in aesthetic relations. An explication of body/ world dependence is provided via the concept of plasticity and a properly Spinozist aesthetics is invoked, but remains to be worked out.

KEYWORDS Merleau-Ponty, Levinas, Spinoza, phenomenology, body, embodiment, space, plasticity
\end{abstract}

The general conditions of esthetic form [...] are objective in the sense of belonging to the world of physical materials and energies: while the latter do not suffice for an esthetic experience, they are a sine qua non of its existence.

- John Dewey, Art As Experience

\section{Introduction: Sensation and Identity}

Among those interested in the history of phenomenology, and the work of Maurice Merleau-Ponty in particular, it is common knowledge that the phenomenology of the body articulated in Phenomenology of Perception owes an incredible debt to Edmund Husserl's second volume of Ideas. ${ }^{1}$ This is the book where Husserl talks at length about the body. The themes of bodily kinaesthetics and motility, operative intentionality, passive synthesis - distinctly corporeal acts in Merleau-Ponty's work - are all taken up from Husserl's analyses. Merleau-Ponty's memorial essay "The Philosopher and His Shadow" testifies to this debt. Even the theme I take up in this paper, what Merleau-Ponty calls the "ontological rehabilitation of the sensible," is credited to Husserl. ${ }^{2}$

Despite the depth of his reliance on Husserl, Merleau-Ponty's intentionality of the body manages to establish a claim that is, at most, dormant in his predecessor's research into embodiment. This is the claim that I am my body. Merleau-Ponty's original contribution to phenomenology, if not philosophy, is "the thesis that I am my body; that I am a subjective object or a physical subject." ${ }^{3}$ Thus, Merleau-Ponty's corporeal 
phenomenology aspires to evacuate the interiority of personal identity by rendering the interior/exterior distinction false and replacing it in the end with the notion of "flesh" (la chair). The flesh is the term he will use to denote the essential identity of body and world, and to indicate that subject and object, seer and seen are cut from the same cloth. This identification effectively reduces personal identity to bodily identity. This is, to be sure, a complex and non-physical form of identity, one which considers the body to be a complex sensible event, or an "haecceity of Nature." The notion of haecceity is employed by Deleuze (and Guattari) in a number of places, including A Thousand Plateaus. Deleuze and Guattari describe an haecceity as an "accidental form," and thereby determine an individual body - in cartographic terms - to be "the sum total of the material elements belonging to it under given relations of movement and rest, speed and slowness (longitude); the sum total of the intensive affects it is capable of at a given power or degree of potential (latitude)." While similar to Deleuze and Guattari's understanding, Merleau-Ponty does not quite affirm the accidental character of corporeal form - his remains bound to the ends of human projects, and is thus informed by the teleology of human perception.

The reduction of personal identity in Merleau-Ponty's phenomenology is an extremely rich one: it leaves room for self-awareness, reflection, and a positive understanding of freedom. This reduced identity is constituted at the basic level by intentionality, the body schema, and the aggregate of acquired habits that enable the body to cope in the practical world. ${ }^{5}$ But it is also constituted by what Merleau-Ponty calls sense experience (le sentir) and sensation (sensation), two different but related terms at play in his text. It is at this level that the body is animated by its "communion" with the world, and it is at this level that the body leads its "anonymous"7 existence, a life whose phenomena are never presented to perception. The body's anonymous existence is formed by what MerleauPonty calls "a past which has never been present." This past names the preperceptual aesthetic life of the body. ${ }^{8}$ In the last analysis, however, Merleau-Ponty invokes a distinction between the divergent multiplicity of sensations and the unifying activity of perception without following up on the challenges that such a distinction poses to his "primacy of perception" thesis, a thesis that commits him to the view that the convergence of perception, which draws together and tames the "unstable" and "alien" events of sensation, takes precedence over sensation's divergent force. ${ }^{9}$ This is a consequence of his allegiance to the phenomenological method, which effectively bypasses ("brackets") the metaphysics of 
sensation, or transubstantiates sensation into "hyletic data."10 It eludes a direct confrontation with the materiality of sensation.

It is not surprising that Merleau-Ponty would hesitate to give pride of place to sensation in his ontology of the body. Sensation is a term endorsed by outdated empiricists and positivists like Ernst Mach, ${ }^{11}$ and phenomenology defines itself in part by its opposition to positivism, behaviorism, and the like. The Phenomenology of Perception opens with a critique of the concept of sensation, which is summed up when MerleauPonty states that a pure sensation "corresponds to nothing in our experience."12 Sensation is always mingled with perception and therefore inseparable from the operations of perception described throughout Phenomenology. By championing perception over sensation, Merleau-Ponty aims to mark his distance from eliminativist and positivist accounts of embodiment, and to render inoperative or derivative the vocabularies of competing theories of behavior and embodiment. After his position is established, however, Merleau-Ponty will once again take up the question of sensation and ask us to see it anew through the lens of perception. In a more direct manner, Levinas will make a case for the irreducible affective significance of sensation.

Now, I will not explore here the methodological and metaphysical problems involved in the phenomenological engagement with sensation, for surely they exist even if the phenomenologist is reluctant to thematize them. ${ }^{13}$ Instead, I want to indicate a few of the positive ways that Levinas and Merleau-Ponty help us understand the aesthetic life of the body. It seems to me that their philosophies give us a prototypical understanding of corporeal plasticity, and make significant contributions to the rehabilitation of sensation as a viable philosophical concept. It is sensation that gives us our material link to the world; it provides a means for grounding identity in the environment and understanding the ways in which our sensory environments can hinder or promote our well-being. A rich conception of the ambivalence of sensation is therefore needed to understand the body's embeddedness in and dependence upon the environment, as well as its identity as an aesthetic object. Once this conception of sensation is clear, I will briefly outline how it contributes to environmental ethics.

I take integrity to denote the identity of the body and to emphasize the nature of its structure. So, when I use this term I do not mean it in the moral sense, but in the sense intended when someone says, "The integrity of the building has been compromised by the earthquake." Here, the analogy between bodies and buildings is drawn deliberately. And this is 
not just for the sake of analogy, but so I can eventually suggest the reciprocal determination of bodies and buildings. However, I also wish to emphasize that a body's integrity, as well as what I call its plasticity, is not entirely determinable by its relations. Plasticity and integrity are internal to the body qua body as long as it exists as an individual, although the duration of its existence as this or that individual (i.e., haecceity) depends upon the relations it enters into. Thus, bodies can be regarded as autonomous, but this by no means commits us to the view that there is something about their individuality that is immune to external influence. The body's integrity and plasticity are both capable of being compromised to the point of annihilation or irreversible automatism, which amount to the same thing. The idea of plasticity helps us think of autonomy beyond the freedom/determinism dichotomy by showing that our susceptibility to influence is what allows us to acquire a structure upon which to act, react to or resist influence.

Before articulating my position on aesthetic identity, I want to say a few things, by way of contrast, about Kant's aesthetics.

\section{Kant's Aesthetics}

The British empiricists who influenced and provoked Kant's thinking were not afraid to speak about sensations and the effect they have on our minds. Locke, Berkeley, and Hume, of course, spoke like this, as did Francis Hutcheson. Hutcheson writes that, "Those Ideas which are rais'd in the Mind upon the presence of external Objects, and their acting upon our Bodys, are call'd Sensations [...] We find that the Mind in such Cases is passive, and has not Power directly to prevent the Perception or Idea, or to vary it at its Reception, as long as we continue our Bodys in a state fit to be acted upon by the external Object." ${ }^{\prime 4}$ Despite the fact that he refers to them as "ideas" (like Berkeley), Hutcheson ascribes the delivery of sensations to external objects (unlike Berkeley). Sensations are objectively given: they are real, not merely epiphenomenal byproducts.

Kant, who was influenced by Hutcheson, holds a parallel view of sensation. Kant writes in the Transcendental Aesthetic of the Critique of Pure Reason: "The effect of an object on our capacity for [re]presentation, insofar as we are affected by the object, is sensation." ${ }^{15}$ For Kant, sensation furnishes the material that the understanding fashions into experience; but it is never apprehended in its pure manifoldness. Since we begin our critical inquiry into the origin of knowledge from organized experience, we can only ever work backward to the disorganization of sensation. That is, we can only infer that formless sensations are given to 
the understanding. This is how the transcendental method works. But if sensation, for Kant, is always already worked up into a representation by our cognitive faculty, then what allows him to claim that something like a pure manifold of sensation actually exists? As Merleau-Ponty points out, we never experience anything of the sort. Kant's picture of cognition requires the concept of sensation, or the sensory manifold, to account for the content of cognition. But beyond its basic architectonic/formal value sensation plays no formative role in the constitution of experience or identity; nor does it hold sway over our capacity to constitute experience. ${ }^{16}$ In short, Kant's transcendental aesthetic idealizes sensation and thereby severs the link - maintained by his predecessor Baumgarten between the mind and the material world.

There is, of course, a practical purpose to Kant's Transcendental Aesthetic. He ensures that the material world and its volatile multiplicity of sensations remain at an infinite remove from the transcendental ego, which signifies the locus of personal identity and the seat of human freedom. Ontologically, a gap exists between the transcendental subject and the world of things. Consequently, the body of the subject is left out of Kant's theory of identity, as Merleau-Ponty does not fail to note in the Phenomenology. ${ }^{17}$ No matter what happens to the body in the physical world, the real identity of the subject is untouched; its freedom is quite immune to the laws of nature and natural events. ${ }^{18}$ This means that, as Samuel Todes puts it, Kant "has no sense of how practice makes the practitioner." ${ }^{\prime 19}$ The price Kant must pay for protecting the freedom of the subject is that he cannot account for how the material of the practical world shapes who we are as individuals.

Angelica Nuzzo has argued that Kant, in fact, does not leave the body out of his equation. If we look to the Critique of Judgment, for instance, we see the embodied dimension of sensibility highlighted by Kant. The experiences of pleasure and displeasure in the face of aesthetic phenomena allow us to " feel ourselves a part of living (i.e., sensible) nature." ${ }^{20}$ She concludes that "[Kant's] general aim is to attribute to human sensibility a new central place in philosophy, thereby steering the philosophical focus from the metaphysics of a 'disembodied soul' to the inquiry into an 'embodied mind'." Kant's modern view of sensibility is broad enough to encompass "the entire realm of the sensual: affections, intuition, sensation, feeling, and imagination." ${ }^{21}$ The innovative moment in Kant arrives when he makes of the body a transcendental condition for aesthetics; a condition that is both "formal" and "ideal," but at the same time corporeal.

In her recent book, Ideal Embodiment, Nuzzo contends that Kant's 
theory of sensibility is ultimately a theory of embodied sensibility and that, “Transcendentally, the knowing subject of Kant's epistemology, the moral agent of his pure ethics, and the evaluating subject of his aesthetic theory of judgment is a rational embodied being."22 The transcendental dimension of embodiment is exemplified in the fact that perception is governed, a priori, by a left/right asymmetry, which corresponds to the asymmetry of our hands. In short, the a priori form of space (the formal aspect of sensible intuition) has left and right built into it. ${ }^{23}$ This asymmetry is not merely physical: it is a transcendental condition of any possible experience.

I would not dispute the existence of a transcendental embodiment in Kant, for Nuzzo's position is both thorough and compelling. It does not, however, succeed in reuniting the body of the subject to the material world. In fact, her argument explicitly resists such a reunion. As a result, the Kantian subject's identity remains beyond the reach of other bodies and, moreover, those bodies must always be seen as themselves constituted by the subject's sensibility and understanding. This entails (1) the impossibility of the subject's identity being either formed or deformed by sensation and (2) a reduction of the otherness of the environment.

As everyone knows, Levinas's entire ethical critique of the history of philosophy works against such a reduction. But instead of following that line of thinking, I will here discuss the way Levinas's aesthetics reinforces the immanence of subject and object by advocating the constitutive function of sensation.

\section{Proto-Plasticity in Carnal Phenomenology}

Perhaps Levinas's most challenging book is Otherwise than Being, wherein he undertakes a sustained deconstruction of sensibility which tacitly engages and operates against the formal version found in Kant. The aim of Levinas's analysis is to show that, "Even when unformed, or deformed, by knowing, sensible intuition can revert to its own meaning." ${ }^{24}$ In large measure, Levinas's argument is an attempt to relocate outside the subject the origin of the world's animation. That is, against Kant, he wants us to see that experience is animated by the difference introduced by the other and not by the synthetic activity of our minds. The relation of our "animate body" or "incarnate identity," as he calls it, "can be understood as an exposure to the other, the passivity of the for-the-other in vulnerability, which refers to maternity, which sensibility signifies." ${ }^{25}$ Sensibility is neither activity nor mere receptivity of preformed representations: sensibility, the site of sensation, is the place at which the identity of the world and the identity of my body come to pass. 
Levinas's account of embodiment in Otherwise than Being ends up overstressing the susceptibility of the body in the face of the sensible environment. The incarnate subject remains always vulnerable to the sensations of the other, its skin invariably exposed to both solicited and unsolicited touching. An entire vocabulary testifies to this inescapable susceptibility:

Vulnerability, exposure to outrage, to wounding, passivity more passive than all patience [...] trauma of accusation suffered by a hostage to the point of persecution, implicating the identity of the hostage who substitutes himself for the others; all this is the self, a defecting or defeat of the ego's identity. And this, pushed to the limit, is sensibility, sensibility as the subjectivity of the subject. ${ }^{26}$

Levinas shifts sensibility and, by consequence, sensation to the center of our thinking about identity. The skin acts as the edge or boundary between subject and world (although this distinction may be simply verbal). As Rudolf Bernet explains,

Even a tight and thick skin has small and large holes that one can adequately call "openings." There are natural openings as well as artificial or forced openings called "wounds." Natural openings are still subject, however, to being forced and wounded. The natural openings allowing for a passage and exchange between the inside and the outside of a body cannot prevent the violence of a traumatic intrusion or expulsion. ${ }^{27}$

The collapsing of subject and object, inside and outside, into the operations of sensibility effectuates a perpetual "breakup of identity" 28 by turning identity into little more than an event of sensibility. The constancy of sensation and our inability to cease the influx of sensible material puts us constantly at risk of having our familiar experiences disfigured, our bodies disabled. This, I think, is what Deleuze has in mind when he writes in his book on Francis Bacon that "sensation is the master of deformations, the agent of bodily deformations." ${ }^{29}$ That sensation animates us, rather than us animating it, is what Deleuze calls the "logic of sensation." Here, I think, he is remarkably close to Levinas.

Although in the final analysis vulnerability is the defining feature of sensibility for Levinas, it is also a site of what he calls alimentation. Sensations are not only what threaten to break up identities, they are also what nourish identities. Our bodies metabolize sensations and thereby incorporate them into their constitution. Conversely, bodies excrete sensations back into the environment. Bodies soak up and radiate aesthetics. 
Just as there is a vocabulary of susceptibility in Levinas's later work, there is a whole vocabulary of alimentation to be found, especially, in Totality and Infinity. This vocabulary includes the notions of living from..., enjoyment, fecundity, satisfaction, and habitation. The consumption of food is merely the most common notion of alimentation: Levinas uses it as a general term for the process of identity constitution. Love, joy, and work for Levinas nourish us just as much as bread or water. The alimentary is nourishment and a source of enjoyment, and it is precisely our enjoyment, or affectivity more generally, which effects our separation from undifferentiated existence - being qua being, the sensible as such - and makes us ecstatic, ${ }^{30}$ autonomous agents. Our affective life enacts the principle of our individuation, makes us practitioners, in Todes's words. Levinas writes:

One does not only exist one's pain or one's joy; one exists from pains and joys. Enjoyment is precisely this way the act nourishes itself with its own activity. To live from bread is therefore neither to represent bread to oneself nor to act on it nor to act by means of it. To be sure, it is necessary to earn one's bread, and it is necessary to nourish oneself in order to earn one's bread; thus the bread I eat is also that with which I earn my bread and my life. But if I eat my bread in order to labor and to live, I live from my labor and from my bread. ${ }^{31}$

In other words, only after we have been affected do we become animated individuals adept at manipulating things and working toward future projects. "Subjectivity," writes Levinas, "originates in the independence and sovereignty of enjoyment."32 Perhaps with a critical glance at Merleau-Ponty and Heidegger, Levinas here makes affectivity a transcendental condition of practical life.

It must be kept in mind that our affective life is incited by the other, nourished by the sensations bestowed upon our sensibility by other bodies. Affectivity is not autoaffection, but alimentation:

Nourishment, as a means of invigoration, is the transmutation of the other into the same, which is in the essence of enjoyment: an energy that is other, recognized as other, recognized [...] as sustaining the very act that is directed upon it, becomes, in enjoyment, my own energy, my strength, me. All enjoyment is in this sense alimentation. ${ }^{33}$

The enjoyment we derive from breathing comes from the other; we live as individuals because the other is there to inhale and exhale. As Silvia Benso has said, the activity of breathing is "an animation [that] does not occur at the level of cognition, theory, or intentionality" but "is only possible at the level of the body, through an incarnation." ${ }^{34}$ On this reading, 
the integral form of the subject is not imposed by the incarnation of a soul; it is generated through an exchange of material. It is what Hans Jonas has called metabolism: through the metabolic process, the organic body trades its matter with the matter of its surroundings. This exchange gives rise to a "living form" whose matter is never the same, but which nevertheless retains a certain integrity. ${ }^{35}$ And as with Levinas's alimentation, this exchange of material need not be an organic process. Inorganic material, even sensations, can provide nourishment for organisms.

Levinas would have us imagine this vitality as an event of generation that is variously described as a "coiling," “folding back," "spiral," and "involution." ${ }^{36}$ The language here is meant to denote the immanent constitution of the individual and the event-like structure of the subject's integrity. The subject is produced as an "eddy"37 of affectivity; it maintains its integrity as long as its common sources of joy or pain affect it. Uncommon, overwhelming, or traumatic affects/sensations threaten to form it into something quite different. The substance of the self, then, is little more than the viscosity or consistency of its sensuous life; or, a finite expression of the sensible. ${ }^{38}$ I would like to call this kind of substance plastic in order to call attention to its event-like structure and its indeterminate, fluid capacity to take on and release form. I will retrieve this Levinasian insight and say more about plasticity below.

There is a complementary, and more familiar, view of embodied subjectivity to be found in Merleau-Ponty. The work of sensation in MerleauPonty's view is often subsumed into his theory of perception, however. He advances a "new status for sensation," attributing to it a "motor physiognomy" and a "living significance." ${ }^{39}$ Sensations are neither mental content nor sense-data nor stimuli. Sensations are transmitted to the body in its dialogue with objects and awaken its sensorium, bringing it to life. They are, in a strong sense, its vitality. Lest we conclude that the body is at the mercy of the sensible environment, however, he repeatedly refers to sensation as a power (puissance) of the body, one that is "synchronized" with the "existential environment." ${ }^{" 40}$ This point is consonant with his transactional view of subject/world relations as well as its more radical expression, the doctrine of the flesh. ${ }^{41}$ Significantly for my argument, this power is determined by the singular array of perspectives that any individual body embodies, and the range of corresponding appearances that attend this set of perspectives. ${ }^{42}$ Power is determined by the totality of aesthetic experiences a body takes in. As Alphonso Lingis puts it, "The sensitive body is the locus of inscription of inner postural axes on external visibility and of external visibility on its inner postural diagram." ${ }^{14}$ 
Consequently, knowing how precisely my body is determined - or, put otherwise, being able to locate my longitude and latitude - is my freedom and my power. This know-how Merleau-Ponty calls "praktognosia," which is a kind of perceptual and practical competence. ${ }^{44}$ This is entailed in Merleau-Ponty's claim that "consciousness is in the first place not a matter of 'I think that' but of 'I can'."45 This I take to be a Spinozist sentiment, with the difference that for Merleau-Ponty it is the habituated body that knows, not the intellect.

There are a number of places in Merleau-Ponty's work where he shows a commitment to the body's plasticity, where he understands its integrity as both indefinitely formable and formative. In his discussions of the habit body and the body schema, for instance, he clearly wants us to regard the body's identity as dialogically constituted and open-ended. As with Levinas, this identity is aggregated and defined by an indeterminate capacity to act and be acted upon. He refers to the body at one point in the Phenomenology as "a mosaic of sensations" with "no specific direction." ${ }^{46}$ This indeterminacy is marked by a threshold, or the absence of a specific locus of identity. Not unlike Hume's stageless theatre of personal identity, Berkeley's Lockean definition of the object as a collection of qualities, ${ }^{47}$ or the Levinasian subject outlined above, Merleau-Ponty's mosaic body has no immutable core. It is, in short, "a fold, which has been made and which can be unmade." ${ }^{48}$ What Deleuze writes about Hume applies for the most part to Merleau-Ponty: "The place is not different from what takes place in it; the representation does not take place in a subject." ${ }^{\prime 9}$

No one will deny that there are numerous incompatibilities between the authors referenced in the last paragraph. Nevertheless, they display a common commitment to thinking the insubstantiality of the subject (or the object, in Berkeley's case), without allowing this subject to be completely dispersed into an impersonal field of forces. This effort I take to be commensurate with the theory of plastic subjectivity. The plastic subject is a dispositional subject, transitory and mutable. Its disposition is informed by its sensory environments and discernible by the sensations it can endure and produce at any given moment. If the identity of the body is marked by a threshold for Merleau-Ponty - a threshold for practical action dictated by the existential environment, the body's habits, and the appearances delimiting its singular perspective - I take this threshold to be plastic in the sense William James intends when he defines plasticity as "the possession of a structure weak enough to yield to an influence, but strong enough not to yield all at once." ${ }^{50}$ Under this definition, corporeal integrity is a mat- 
ter of degree and is never precisely fixed. Integrity will be reinforced or compromised by the aesthetic environment and the entire range of sensory encounters it engenders, from personal communication device interfaces to urban greenways, from airport terminal acoustics to the building materials and lighting of Kiasma in Helsinki.

The threshold of identity is explored at length in Merleau-Ponty's treatment of painting, particularly the work of Cézanne. He explicitly draws an analogy between the body and the work of art, which enables us to understand what he takes corporeal identity to be. "For each object," Merleau-Ponty writes, "as for each picture in an art gallery, there is an optimum distance from which it requires to be seen." ${ }^{2}$ Between the body and the work of art there lies a privileged perceptual position that reveals the true identity of the work. This position allows me to "identify the object [or painting] in all its positions, at all distances, in all appearances, insofar as all the perspectives converge towards the perception which I obtain at a certain distance and with a certain typical orientation. ${ }^{53}$ Of course, the position at which a painting's identity appears is not exact, but variable to a degree. This variability, however, can devolve into the obliteration of the painting's identity. Move too far away from the painting and you lose clarity. At the extreme, it disappears completely from sight. The identity of a work of art is thus determined by an "ideal limit," a threshold that determines how close is too close and how far is too far for perceiving it. This ideal limit is what is studied in Cézanne's painting, which is why his objects often appear on the verge of losing their integrity. ${ }^{54}$ If the body is like a work of art, a mosaic in particular, then its integrity will admit of a set of limits beyond which it ceases to be this body and becomes another body altogether. There will be no substantial core underlying its aesthetic variation; within that set of limits it will retain its integrity (or form or clarity), even if some components are added or removed. ${ }^{55}$ This is what it means to be a plastic body.

\section{Nourishing Spaces}

Now, if the integrity of the body depends on the aggregate of sensations it receives, then the spaces it inhabits (to take just one example of an aesthetic environment) are an essential constituent of its identity. Spaces, too - whether natural or built - offer a source of alimentation, their own unique sensory mosaic. Presumably we want to cultivate spaces that enable, rather than disable, our bodies. In the case of built spaces, we want their integrity to at least reinforce and, ideally, promote or augment our integrity. ${ }^{56}$ An architectural philosophy whose buildings seek primarily to 
adapt to the human body, or which takes the reality of space to be a product of intentional perceptual syntheses, is inadequate from an ecological perspective, and not least of all because it is anthropocentric. Further, we want to avoid habitats that compromise us by pushing the tolerance of our plasticity beyond its breaking point. From the standpoint of plasticity, this breakage is the very meaning of death. We will then want to multiply the habitats that increase our capacity to affect and be affected, that is, increase our power to exist. For this to occur, environmental aesthetics and architecture must confront the plasticity of the body. Can a phenomenological aesthetics accomplish this? Not if it neglects the materiality of sensation.

Ed Casey, following Merleau-Ponty (and implicitly Bourdieu), defines a habitat as a familiar kinaesthetic situation, one which gives rise to a practical aptitude required for orienting oneself in the environment. In a habitat, he writes, "we can be 'ethical' in the originary sense of the word, which implies a community of like-minded (but not necessarily like-bodied) creatures." ${ }^{57}$ Habitats sustain us and offer us the opportunity to cultivate ourselves as long as we are willing and able to meet their demands. When we do, they enable in us a certain set of dispositions for action. This "power of orientation," or habitus, dictates what we can and cannot do. ${ }^{58}$ Insofar as a habitus is the internalization of a habitat, the structure of the body exemplifies and expresses the structure of the habitat. And this is not because the body is flexible or adaptable, but because it is plastic: it can fashion its habitat, and therefore its habitus, just as much as it is fashioned by it. ${ }^{59}$ A neglect or careless cultivation of the habitat risks violating its integrity and, consequently, endangering that of our bodies.

Architectural theorists attuned to the phenomenology of the body foreground the body's reflection of its environment. Peter Zumthor speaks of the "atmosphere" of built spaces and how our "emotional sensibility," rather than our sense perception or judgment, apprehends it. ${ }^{60}$ Architecture, for Zumthor, is about how atmosphere embraces the bodies dwelling within it. He writes:

It's like our own bodies with their anatomy and things we can't see and skin covering us - that's what architecture means to me and that's how I try to think about it. As a bodily mass, a membrane, a fabric, a kind of covering, cloth, velvet, silk, all around me. The body! Not the idea of the body - the body itself! A body that can touch me. ${ }^{61}$

In a similar vein, Juhani Pallasmaa writes of how our bodies assume 
atmospheres in their skeletal and sensory structures. This structure is first embodied in the architect, and then transmitted into the body of the inhabitants. ${ }^{62}$ Such a transmission is possible, I would contend, because the body is plastic, susceptible to spatial aesthetics but also capable of apprehending the power embedded in any space that does not compromise its integrity. The creative aspect of the plastic body is its capacity to stylize this power into new buildings that it can then integrate into itself. My contention is that these body/building transactions occur first and foremost at the impersonal, non-phenomenal level of sensation. This level is non-intentional and with "no specific direction," as MerleauPonty admits. This means that aesthetic design cannot be content with the data provided by perception. Perception cannot fully predict how an environment will affect the senses; nor can it know which environments will enhance the body's power, or diminish it. In a sense, these events will happen by chance. Phenomenology, for all its promise, has trouble handling the non-phenomenal and the non-intentional. This is precisely because phenomenality and intentionality are fundamental elements of its understanding of experience. As Pallasmaa ultimately puts it, "the generative force [of the body and the building] lies in the intentions." 63

As if despite their allegiance to phenomenological principles, Levinas and Merleau-Ponty make valuable contributions to the rehabilitation of sensation as a concept, as we have seen. But these contributions oftentimes seem in tension with the first-person perspective of phenomenology, assuming instead the form of metaphysical speculation on the genesis of subjectivity and the materiality of the sensible realm. Without question, such speculation is required for a complete understanding of corporeal identity. Without it we are left only with description. Design, architectural and otherwise, needs more than description if it is going to realize the unforeseen power of our bodies.

Let me illustrate an earlier point: our habitat is reflected in our habitus. We may recall the habits taken on by Thoreau at Walden Pond. Only a certain set of habits were available to him if he desired to be shaped by that unique habitat called Walden. A balance had to be struck between his efforts at cultivation, on the one hand, and his yielding to the environment, on the other, in order to preserve his integrity along with Walden's. ${ }^{64} \mathrm{He}$ could till the land, but not so much that its fertility would be diminished. He could last the winter, but only if the season's conditions did not exceed his fortitude. We might imagine Walden and consider the unique set of sensations that make up its aesthetic identity, as well as the sensations put into that habitat by Thoreau himself. ${ }^{65}$ It 
could be said that, in a strong sense, Thoreau became Walden while living there; that Thoreau would not be Thoreau had he not inhabited that space. But what would Walden have become if Thoreau failed to respect its integrity? Imagine the sensations that would result if the threshold separating and uniting Thoreau and Walden were compromised by either of them.

The relation of body and environment is not always harmonious, however. Indeed, it is often, if not always, volatile. Sensations, as MerleauPonty teaches, are the unstable, the alien. They are alimentary, on the one hand, but on the other they threaten always to break us up. Given the volatility of sensation and the plasticity of our identities, we need an ethical principle that will tell us what kind of environment we should endorse. Architect Michael Benedikt offers a useful definition of value to accompany the aesthetics of embodiment that we have sketched thus far. He says: “positive value' is what we attribute to that which intensifies and/or prolongs life. Conversely, 'negative value' is what we attribute to that which dilutes and/or shortens life." ${ }^{\prime 6}$ This, again, is a sentiment very close to Spinoza.

Benedikt acknowledges the anthropocentrism at work in his definition, but nothing prevents us from applying it to existence in general. The point is to increase power and proliferate the possibilities of existence wherever we can, whether we are constructing or building or restoring or conserving. But whose power? Ideally, any creature capable of giving and receiving sensations. Does this exclude inanimate objects? Not necessarily, for they too belong to the aesthetic economy and participate in the intensification and prolongation of "life" understood as an integrated sensory system. The obvious obstacle here is adjudicating situations where power needs to be sacrificed in the name of some other end, but this problem must be deferred for now.

\section{Spinozist Aesthetics and the Future of Plasticity}

It is rare to find two figures more committed to the renewal of sensation after Kant than Merleau-Ponty and Levinas. I have tried to indicate some of the ways they can enrich our understanding of sensation, but I have also raised some concerns about the usefulness of phenomenology's approach to embodiment and environmental aesthetics. Its anthropocentric perspective may very well do justice to the richness and complexity of human existence, but its descriptions of spatiality and aesthetic experience must always refer back to the intentionality of the subject. It is true that this subject is seen as embedded and situated in a concrete 
environment, but this concreteness is always informed by the teleological practice of the subject. Consequently, the existential features of the lifeworld are privileged over the material, and the embodied subject is regarded as relatively free to transcend its situation. But an existential situation is not a material environment. Their dynamics are different. An environmental aesthetics or architectural theory driven by the phenomenologist's picture of embodiment will accommodate the body as lived, existential project, but it will do so at the neglect of the material basis of aesthetic identity.

Although they are amenable to plasticity, it is not necessary to return to the phenomenologists to advance the concept. Indeed, I have suggested that the metaphysics of phenomenology restricts a complete commitment to the plastic body. Nor is it necessary to go to Deleuze, or even James, as I have done here, to find the concept at work in the history of philosophy. Plasticity is operative in prototypical form in most "anti-essentialist" approaches to human nature, embodiment, and personal identity. Catherine Malabou has recently found the concept in Hegel and taken up research in neuroscience with a view to developing a politics of plasticity. ${ }^{67}$ Neural plasticity has become an indispensable idea for contemporary brain scientists; it is the empirical equivalent of the plasticity we find in James's speculative neurology. For my part, I would argue that the philosophy of the body we find in Spinoza is centered on the concept of plasticity and preferable to the phenomenological body for several reasons.

First, Spinoza's monistic ontology considers bodies as expressions of a single substance, rather than as individual loci of perception or consciousness. Human beings hold no privileged position in the constitution of experience or the environment, which means that they are no more capable of transcending the events of the material world than any other bodies. This leveling of the field of being to a single plane of nature has a democratic edge to it, eliminating the distinction between human and nonhuman, natural and artificial, and the hierarchy of beings. Second, instead of regarding the immanence of nature as the absence of freedom, he shows us how to see our determination as our freedom: our power to exist is based on nothing other than the ways we are determined by our material conditions, our precise longitude and latitude. Third, consciousness, intentionality, and interiority are left out of the picture of embodiment; we must think the body and its embeddedness in their materiality alone. Everything the body can do must be accounted for in terms of "corporeal surfaces, in terms of rotations, convolutions, 
inflections, and torsions of the body itself." ${ }^{68}$ Reducing the body to its surface (immanent) identity obliges us to shift our attention toward its aesthetic relations.

For Spinoza, a body is never a pure individual. It is always a composite, an aggregate or ecology of bodies working together as an individual. Some human bodies in a building or in the street can unite to form an individual; several animal and inanimate bodies can unite to form an individual; some furniture, paintings, and lighting fixtures can unite to form an individual, or they may fail to do so. It all depends on how the surfaces affect each other and the effect produced. An individual is an ecological, not a perceptual, phenomenon, with an identity determined by its singular disposition, that is, its power to affect and be affected. ${ }^{69}$ This formula names the plasticity of the Spinozist body. Its power is formally variable, which means that some of the bodies in the composite can be substituted or eliminated, as long as the composite's effect remains intact. From a practical point of view, the body's identity is gleaned by asking, What can the body do? Or, What is its pain and pleasure threshold? To answer these questions, we need to know which sensations the body can endure and which sensations the body can exhibit. This is the task of design teams, whether in the domain of art, architecture, virtual environments, or urban planning. If we do not know what a body can do, then we must actively pursue, by design, the power of the unperceivable and unpredictable. A Dionysian ethic of exposure and non-censorship suggests itself: "Dionysus affirms all that appears [...] and appears in all that is affirmed." ${ }^{\prime 70}$ A fully worked out Spinozist aesthetics can help us embrace this principle. ${ }^{71}$ Spinoza's philosophy has already had a significant impact on the deep ecology movement, and I suspect his contribution to architecture would not be insignificant. ${ }^{72}$ In sum, his promise lies in his plastic conception of embodiment, his materialist framework, as well as his democratic theory of bodies and environmental relations. ${ }^{73}$ His philosophy affirms the equality of bodies, the advantage of cultivating convivial ecological habits, and an equitable distribution of power, all of which are at stake in environmental ethics and political ecology.

\section{Notes}

1. Edmund Husserl, Ideas Pertaining to a Pure Phenomenology and to a Phenomenological Philosophy, second book, trans. Richard Rojcewicz and Andre Schuwer (Dordrecht: Springer, 1990). 
2. Maurice Merleau-Ponty, "The Philosopher and His Shadow," Signs, trans. Richard C. McCleary (Evanston: Northwestern University Press, 1964), 167.

3. Stephen Priest, Merleau-Ponty (London: Routledge, 1998), 57.

4. Merleau-Ponty, "The Philosopher and His Shadow," 165.

5. Maurice Merleau-Ponty, Phenomenology of Perception, trans. Colin Smith (London: Routledge and Kegan Paul, 1962), 142-143.

6. Ibid. 212.

7. On anonymity, see Phenomenology of Perception, 215. In this vein, we could invoke the autonomic nervous system as a primary dimension of the body, which functions for the most part below the level of consciousness. From the perspective of phenomenology, this system must remain anonymous, never present directly as a phenomenon.

8. Merleau-Ponty, Phenomenology of Perception, 242, and Alia Al-Saji, "A Past Which Has Never Been Present': Bergsonian Dimensions in Merleau-Ponty's Theory of the Prepersonal," Research in Phenomenology 38 (2008), 41-71. Since sensation belongs always to the past, we might say that it exists virtually (which is not to say merely potentially). Its effects are always actualized, but never present to perception, which remains directed upon the future. Note that I am using "aesthetic" here in a broad sense to refer to the sensory environment writ large.

9. Merleau-Ponty, Phenomenology of Perception, 230.

10. See $\mathbb{3} 6$ of Edmund Husserl, Ideas, trans. W. R. Boyce Gibson (New York: Collier, 1962), where Husserl makes sensation (now termed "hyletic data") immanent to consciousness, thus attenuating, if not negating, its externality.

11. See Ernst Mach, The Analysis of Sensations, trans. C. M. Williams and Sydney Waterlow (New York: Dover, 1959).

12. Merleau-Ponty, Phenomenology of Perception, 3.

13. I have looked at length at these issues in "Sensation Rebuilt: Carnal Ontology in Levinas and Merleau-Ponty," PhD diss., Duquesne University, May 2010.

14. Quoted in Davide Panagia, The Political Life of Sensation (Durham: Duke University Press, 2009), 24.

15. Immanuel Kant, Critique of Pure Reason, trans. Werner S. Pluhar (Indianapolis: Hackett, 1996), B34/A2O.

16. Furthermore, he is not entitled to Hutcheson's claim that objects cause sensations in us. Causality occurs only in the phenomenal world; Kant cannot maintain that noumenal entities impress themselves upon us, thus inciting the mind to activity. This is originally, I believe, Maimon's objection.

17. Merleau-Ponty, Phenomenology of Perception, 303.

18. The view that human freedom is beyond the reach of nature - namely, that human and natural laws are completely independent from one another - is glimpsed when Kant writes in the third Critique: "The great gulf that separates the 
supersensible from appearances completely cuts off the domain of the concept of nature under the one legislation, and the domain of the concept of freedom under the other legislation, from any influence that each (according to its own basic laws) might have had on the other" (Immanuel Kant, Critique of Judgment, trans. Werner S. Pluhar [Indianapolis: Hackett, 1987], Introduction, IX, 195).

19. Samuel Todes, Body and World (Cambridge, MA: MIT Press, 2001), 173. My emphasis.

20. Angelica Nuzzo, "Kant and Herder on Baumgarten's Aesthetica," Journal of the History of Philosophy 44, no. 4 (October 2006), 587.

21. Nuzzo, "Kant and Herder," 578.

22. Angelica Nuzzo, Ideal Embodiment: Kant's Theory of Sensibility (Bloomington: Indiana University Press, 2008), 5.

23. Ibid. 10-11.

24. Emmanuel Levinas, Otherwise than Being; or, Beyond Essence, trans. Alphonso Lingis (Pittsburgh: Duquesne University Press, 1997), 63.

25. Ibid. 71.

26. Ibid. 15 .

27. Rudolf Bernet, "The Encounter with the Stranger: Two Interpretations of the Vulnerability of the Skin," The Face of the Other and the Trace of God, ed. Jeffrey Bloechl (New York: Fordham University Press, 2000), 45-46.

28. Levinas, Otherwise than Being, 14.

29. Gilles Deleuze, Francis Bacon: The Logic of Sensation, trans. Daniel W. Smith (Minneapolis: University of Minnesota Press, 2003), 36.

30. For Heidegger, Dasein is always ecstatically outside itself insofar as it is fundamentally a temporal being. Among the three "ecstases" of time, the future is the most primordial for Dasein. Dasein is a future-directed being, engaged in projects, for itself, and always being towards its own death. The same is true for Merleau-Ponty's subject of perception. If temporality is a basic ontological structure of Dasein's being for Heidegger, then affectivity is such for Levinas. On temporality, see Martin Heidegger, Being and Time, eds. John Macquarrie and Edward Robinson (San Francisco: Harper Collins, 1962), 377-378ff.

31. Emmanuel Levinas, Totality and Infinity, trans. Alphonso Lingis (Pittsburgh: Duquesne University Press, 1969), 111.

32. Ibid. 114 .

33. Ibid. 111.

34. Silvia Benso, "The Breathing of the Air: Presocratic Echoes in Levinas," Levinas and the Ancients, eds. Brian Schroeder and Silvia Benso (Bloomington: Indiana University Press, 2008), 20.

35. Hans Jonas, The Phenomenon of Life (Evanston: Northwestern University Press, 1966), 71, n.13. The concept of metabolism need not be confined to philo- 
sophical biology, but can be deployed generally as a description of the genesis of form out of any material interaction. On the immanent genesis of form, see Manuel DeLanda, "Immanence and Transcendence in the Genesis of Form," The South Atlantic Quarterly 96, no. 3 (Summer 1997), 499-514.

36. See, for example, Levinas, Totality and Infinity, 118; Otherwise than Being, 73; and Emmanuel Levinas, Existence and Existents, trans. Alphonso Lingis (Pittsburgh: Duquesne University Press, 1988), 81.

37. Levinas, Totality and Infinity, 115.

38. Incidentally, Merleau-Ponty calls affective life "the birth of being for us," in Phenomenology of Perception, 154.

39. Ibid. 209.

40. Merleau-Ponty, Phenomenology of Perception, 211. On the body as power, see also Phenomenology, 142, 143, 210, 302. It should be noted that Merleau-Ponty specifies that the body is synchronized with the existential world, not the sensible, which remains at all times foreign and disruptive of the body's competence. That is, there is a basic asynchrony or dissymmetry between the subject of perception and the sensible environment.

41. The "flesh" names the impersonal, anonymous form of the sensible in general. It is what unites both seer and seen; or, more precisely, it is the visible as such. Merleau-Ponty calls the flesh the common "element" that subjects and objects emerge from, indicating that "the thickness of flesh between seer and the thing is constitutive for the thing of its visibility as for the seer of his corporeity." See Maurice Merleau-Ponty, The Visible and the Invisible, trans. Alphonso Lingis (Evanston: Northwestern University Press, 1968), 135.

42. Merleau-Ponty, Phenomenology of Perception, 302.

43. Alphonso Lingis, Foreign Bodies (New York: Routledge, 1994), 15.

44. Merleau-Ponty, Phenomenology of Perception, 140. Lingis takes sides with Levinas, against Merleau-Ponty, when he writes in Foreign Bodies, 24-25: "In the substance of our competence other bodies emerge, ethereal and phantasmal - bodies that materialize forces and powers that are other than those of praktognostic competence."

45. Merleau-Ponty, Phenomenology of Perception, 137.

46. Merleau-Ponty, Phenomenology of Perception, 249. Conceiving the body as a mosaic can be useful for thinking about the constitution of racial identities. This work is being done, although not from a phenomenological perspective, by historian Mark M. Smith. See How Race is Made: Slavery, Segregation, and the Senses (Chapel Hill: University of North Carolina Press, 2006).

47. George Berkeley, A Treatise Concerning the Principles of Human Knowledge (Indianapolis: Hackett, 1982), Part I, $\mathbb{1}$.

48. Merleau-Ponty, Phenomenology of Perception, 215. 
49. Gilles Deleuze, Empiricism and Subjectivity, trans. Constantin V. Boundas (New York: Columbia University Press, 1991), 23, emphasis added. Deleuze comments on the personal identity section of Hume's Treatise.

50.William James, Psychology: The Briefer Course (Mineola: Dover, 2001), 2. Catherine Malabou draws an important distinction between plasticity and flexibility when she says that, "To be flexible is to receive a form or impression, to be able to fold oneself, to take the fold, not to give it. To be docile, to not explode. Indeed, what flexibility lacks is the resource of giving form, the power to create, to invent or even to erase an impression, the power to style. Flexibility is plasticity minus its genius." See her What Should We Do with Our Brain?, trans. Sebastian Rand (New York: Fordham University Press, 2008), 12. The creative aspect of plasticity is central to the concept, even though I have downplayed that aspect here.

51. Merleau-Ponty, Phenomenology of Perception, 150: "The body is to be compared, not to a physical object, but rather to a work of art."

52. Ibid. 302.

53. Ibid.

54. Maurice Merleau-Ponty, "Cézanne's Doubt," in Sense and Non-Sense, trans. Hubert L. Dreyfus and Patricia Allen Dreyfus (Evanston: Northwestern University Press, 1964), 15.

55. Questions regarding the prosthetic, machinic, and non-organic nature of the body arise at this point.

56. I am thinking here of what Erich Schiffman calls the "edge" of a yoga posture (asana). An edge is defined by the intensity of the posture, the point at which the body is stretched to the verge of pain, but at the same time increasing its physical potential. "Edges," writes Schiffmann, "are marked by pain and define your limits." Without this degree of pain, "there is no challenge to the muscles, no intensity, no stretch, and little possibility for opening. Going too far, however, is an obvious violation of the body, increasing the possibility of both physical pain and injury." See Yoga: The Spirit and Practice of Moving into Stillness (New York: Pocket Books, 1996), 74. I am indebted to my wife, Rachel Shandor, for pointing me to this passage and demonstrating its meaning.

57. Edward S. Casey, Getting Back into Place (Bloomington: Indiana University Press, 1993), 292.

58. Casey, Getting Back into Place, 293. See also Merleay-Ponty, Phenomenology of Perception, 142-143 on the cultivation of habit as the acquisition of power. For full treatment of the concept of habitus, see Pierre Bourdieu, The Logic of Practice, trans. Richard Nice (Stanford: Stanford University Press, 1992).

59. Malabou, What Should We Do with Our Brain?, 12. Gail Weiss criticizes Bourdieu's concept of habitus for being too deterministic, for not allowing enough room for individual freedom or self-stylization of the habitus. Bour- 
dieu, then, has "difficulty explaining how radical change or spontaneous innovation can really occur either on an individual or on a societal level." She tries to overcome Bourdieu's defects by supplementing his thinking with the insights of phenomenologists like Merleau-Ponty. See Refiguring the Ordinary (Bloomington: Indiana University Press, 2008), 86-87. I remain skeptical about the reality of radical change, and therefore sympathize with Bourdieu's quasideterministic characterization of the habitus.

6o. I want to suggest that notions like "atmosphere," "aura," and "ambience" can be accounted for in terms of sensation. In a sense, then, to say that something possesses an atmosphere, without specifying the elements of that atmosphere, is a failure of description. Ideally, a unique atmosphere should be specifiable in terms of the singular set of sensations it gives off - its sensory signature or fingerprint, so to speak.

61. Peter Zumthor, Atmospheres (Basel: Birkhäuser, 2006), 23.

62. See Juhani Pallasmaa, "An Architecture of the Seven Senses," Questions of Perception, eds. Steven Holl et al. (San Francisco: William Stout, 2008), 36-37. Pallasmaa sees the skin as central to this process. He explores this further in The Eyes of the Skin: Architecture and the Senses, second edition (Chichester: Academy Press, 2005).

63. Pallasmaa, "An Architecture of the Seven Senses," 41.

64. This ethical sentiment is highlighted in Frank Lloyd Wright's writing on the natural home, where his conception of architectural integrity is motivated by a balanced concern for the natural and built environments. This means, above all, that his design pays particular attention to the interface of site and building, and tries to preserve the integrity of both while at the same time introducing a new aesthetic dimension. As a result, the building site is intensified, not degraded or diluted. See Wright's essay, "Integrity," in The Natural House (New York: Bramhall House, 1954).

65. The "Sounds" chapter of Walden illustrates the aural identity of the book's namesake. The birdsongs, train whistles, cars, bells, etc. that Thoreau records are what get coded as "Walden." From the standpoint of the ear, Walden is just this aggregate of sounds. See Henry David Thoreau, Walden and Other Writings (New York: Bantam, 1983).

66. Gong Szeto, "Towards a General Theory of Value: An Interview with Michael Benedikt." March 6, 2003. American Institute of Graphic Arts, http://gain2. aiga.org/content.cfm?Alias=michaelbenedikt\&rca=michaelbenediktı \&pff=1

67. In addition to What Should We Do with Our Brain?, see Malabou's The Future of Hegel: Plasticity, Temporality, and Dialectic (London: Routledge, 2004) and Plasticity at the Dusk of Writing: Dialectic, Destruction, Deconstruction (New York: Columbia University Press, 2009). 
68. Elizabeth Grosz, "Lived Spatiality," Architecture from the Outside: Essays on Virtual and Real Space (Cambridge, MA: MIT Press, 2001), 32.

69. See the "brief preface concerning the nature of bodies" in Part II (pp. 72-76) of Baruch Spinoza, Ethics, trans. Samuel Shirley (Indianapolis: Hackett, 1992).

70.Gilles Deleuze, Nietzsche and Philosophy, trans. Hugh Tomlinson (New York: Columbia University Press, 1983), 17.

71. James C. Morrison, "Why Spinoza Had No Aesthetics," Journal of Aesthetics and Art Criticism 47, no. 4 (Fall 1989), 359-365, argues that Spinoza had no aesthetics, and for good reason. If we take aesthetics in the expanded sense that I have advocated in this essay, rather than in the narrow sense of "philosophy of art and beauty" employed by Morrison, then Spinoza has much to offer us.

72. See, for instance, Eccy de Jonge, Spinoza and Deep Ecology (Burlington: Ashgate, 2004) and Gilles Deleuze, Spinoza: Practical Philosophy, trans. Robert Hurley (San Francisco: City Lights, 1988).

73. On this point, see Timothy Morton's recent book, The Ecological Thought (Cambridge, MA: Harvard University Press, 2010). 